\title{
PENANAMAN KARAKTER PEDULI SOSIAL PADA SISWA SEKOLAH DASAR
}

\author{
Muhamad Arif ${ }^{1}$, Jesica Dwi Rahmayanti ${ }^{1}$, Fitri Diah Rahmawati ${ }^{1}$ \\ ${ }^{1}$ STAI Al-Azhar Menganti, Gresik \\ *Corresponding email: muhamadarif070593@gmail.com
}

Naskah diterima: 24 Juli 2021| Disetujui: 20 Agustus2021 | Diterbitkan: 22 Agustus 2021

\begin{abstract}
Strengthening the character in students must be carried out optimally so that it supports strengthening the identity of a nation that cares regardless of race and culture or even religion. In some cases about the lack of social care around the community, such as when there are friends or people, the first thing they do is not help them. However, on the contrary, some individuals are more busy capturing the moment by making videos or taking pictures, or spreading them on social media networks. This study uses a qualitative method with an empirical case study approach at Muhammadiyah 1 Menganti Gresik Elementary School. The primary data sources in this study were classroom teachers from grades 1-6. The data collection method used observation, semi-structured interviews and documentation. In the process of collecting data, researchers used data analysis techniques from Miles and Hubarman. The process of inculcating social care characters in students, there are two stages: First, is the example of the teacher. Second, is habituation that must be done continuously. Meanwhile, in strengthening the two stages, several programs, namely: philanthropy, takjil on the road, donations for victims of natural disasters, social services, distribution of qurban meat and qurban food security.
\end{abstract}

Keywords: Character, Social Care, Elementary School, Philanthropy, Donations

\begin{abstract}
Abstrak: Beberapa kasus tentang kurangnya kepedulian sosial di sekitar lingkungan masyarakat, seperti ketika ada teman atau orang (tertimpa musibah), hal pertama yang dilakukan bukanlah menolongnya. Namun, justru sebaliknya beberapa individu lebih sibuk mengabadikan momen tersebut dengan memvidio, memotret, atau menyebarkan pada jejaring media sosial. Penelitian ini menggunakan metode kualitatif dengan pendekatan studi kasus latar empiris di Sekolah Dasar Muhammadiyah 1 Menganti Gresik. Sumber data primer pada penelitian ini yaitu guru kelas mulai dari kelas 1-6. Metode pengumpulan data menggunakan observasi partisipatif, wawancara semi terstruktur dan dokumentasi pada Sekolah Dasar Muhammadiyah 1 Menganti Gresik. Dalam proses pengumpulan data peneliti menggunakan teknik analisis data dari Miles and Hubarman. Proses penanaman karakter peduli sosial pada peserta didik, terdapat dua tahapan yang dilakukan Sekolah Dasar Muhammadiyah 1 Menganti Gresik. Pertama, adalah keteladanan dari guru. Kedua, adalah pembiasaan yang harus dilakukan secara continue. Sedangkan dalam menguatkan kedua tahapan tersebut, Sekolah Dasar Muhammadiyah 1 Menganti Gresik, beberapa program, yaitu filantropi, takjil on the road, donasi korban bencana alam, bakti sosial, pembagian daging qurban, dan qurban ketahanan pangan.
\end{abstract}

Kata Kunci: Karakter, Peduli Sosial, Sekolah Dasar, Filantropi, Donasi 


\section{PENDAHULUAN}

Pendidikan adalah sebuah usaha sadar yang dilakukan oleh peserta didik untuk menemukan kebenaran yang absolut secara kritis dan objektif. Nuryanto, memberikan sebuah pandangan posisi pendidikan sebagai solusi pada realitas sosial. Maka, posisi pendidikan dalam filsafat praktis mempunyai tiga strata, yaitu naming, reflecting, and acting (Nuryanto, 2008). Maka, pendidikan seharusnya dapat menjadi solusi dari berbagai permasalahan sosial masyarakat. Salah satu tujuannya adalah mencetak peserta didik yang peduli pada sosial sekitarnya. Ganiem dalam bukunya mendefinisikan peduli sebagai tindakan dasar yang dimiliki pada diri seseorang, sehingga menimbulkan perhatian dan tindakan terhadap permasalahan yang diketahuinya (Ganiem \& dkk, 2015). Sedangkan pembahasan definisi sosial yang mempunyai beberapa teori, sebagaimana Durkheim menjelaskan tentang posisi sosial dalam masyarakat adalah sebuah kelompok yang mempunyai aturan (kesepakatan bersama) sehingga dapat mempengaruhi pribadinya (Wirawan, 2012). Maka, penanaman peduli sosial dapat dilakukan secara beriringan dengan dukungan yang terdapat pada masyarakat sekitar. Sehingga peduli sosial tidak hanya sebagai pendefinisian, namun peduli sosial adalah perilaku yang dilakukan sesuai dengan aturan yang sudah disepakati. Selain itu realitas sosial mempunyai beberapa catatan penting untuk dilakukan perbaikan sedini mungkin. Sebagaimana Nursalam dkk, mengarisbawahi tentang pentingnya menumbuhkan karakter peduli sosial pada peserta didik melalui tiga tahapan (Nursalam et al., 2020). Pertama, penguatan kompetensi peserta didik sehingga dapat merubah pemikiran tentang pentingnya peduli sosial disekitarnya. Kedua, penumbuhan keinginan dalam bertindak yang baik kepada seluruh orang di sekitarnya, sehingga pada tahapan ketiga peserta didik dapat melakukan pembiasaan dalam memberikan uluran tangan kepada yang membutuhkan. Maka, posisi penting dalam penanaman karakter peduli sosial pada peserta didik khususnya tingkat Sekolah Dasar/Madrasah Ibtidaiyah perlu diimplementasikan semaksimal mungkin.

Penanaman peduli sosial menjadi salah satu dari 18 pendidikan karakter yang diatur oleh Kementerian Pendidikan dan Kebudayaan Republik Indonesia. Hal ini menjadi dasar untuk menguatkan momentum Indonesia kuat di 2045. Rokhman juga memberikan catatan tentang potensi Indonesia diseratus tahun setelah kemerdekaan, menjadi sebuah momen terkuat jika dapat dimanfaatkan secara tepat. Menjadi salah satu tempat terbaik adalah pada dunia pendidikan, Rokhman memberikan petikan bahwa pendidikan di Indonesia harus beralih fokus dari tempat mentransfer ilmu, namun ditambahkan sebagai tempat pembentukan sikap, perilaku, dan 18 karakter yang sudah tercantum pada Permendikbud Indonesia (Rokhman et al., 2014). Maka, disinilah peran pendidik tidak dapat tergantikan. Sejalan dengan gagasan tersebut, pada dasarnya para pendidik mempunyai keharusan dalam penanaman karakter pada diri siswa, terutama karakter peduli sosial 
pada peserta didik yang merupakan sebuah sikap kepekaan dalam bertindak untuk memberikan bantuan kepada masyarakat sekitar yang membutuhakan (Hartono, 2014).

Kajian penanaman karakter peduli sosial juga menjadi fokus riset yang cukup menarik untuk didiskusikan (Abdusshomad, 2020). Sehingga beberapa peneliti melakukan riset dengan tema tersebut. Seperti pada riset Setiawatri dan Kosasih tentang implementasi dari karakter peduli sosial yang dilakukan oleh sekelompok masyarakat di daerah Kuningan Jawa Barat. Melalui perwakilan dari berbagai pemeluk agama, yaitu Islam, Katolik dan Agama Djawa Sunda, salah satu yang terlihat adalah adanya gotong royong antar agama lain dalam kegiatan pembangunan rumah ibadah, serta infastruktur yang mendukungnya. Selain itu adanya saling membatu pada masyarakat yang tertimpa musibah (Setiawatri \& Kosasih, 2019). Sehingga proses pembentukan karakter peduli sosial dapat terus berjalan tanpa adanya paksaan bahkan diskriminasi, meskipun berbeda budaya, ras, dan agama.

Karakter peduli sosial menjadi salah satu karakter yang wajib dikembangkan di Negara Indonesia, hal ini disampaikan Sari dari hasil risetnya, bahwa pemantapan watak (karakter) pada diri peserta didik harus dilakukan secara maksimal sehingga mendukung dalam memperkuat jati diri bangsa yang peduli tanpa memandang ras dan budaya atau bahkan agama. Karakter peduli sosial yang dilakukan pada siswa SMAN 4 Balikpapan baik secara individu maupun secara umum. Beberapa program yang dimasukkan mulai dari penguatan identitas ke-Indonesiaan dalam pelajaran pendidikan kewarganegaraan, ekstrakurikuler, keteladanaan (contoh), serta kejadian spontanitas (membantu korban bencana/orang membutuhkan) yang mengarah pada kepekaan peduli sosial siswa (Sari, 2016). Pada posisi inilah seorang guru perlu memberikan bimbingan secara maksimal pada diri siswa karena penanaman karakter peduli sosial memerlukan sebuah proses yang cukup panjang. Murray dkk, memberikan penguatan dengan hasil risetnya yang menyatakan bahwa peran dari pendidik (guru), ketika siswa di sekolah dan peran dari orang tua, (ketika siswa di rumah) secara inklusif sangatlah penting dalam menanamkan karakter peduli sosial yang maksimal pada diri siswa pada usia sekolah dasar (Murray et al., 2020). Karena beberapa kasus banyak ditemukan tentang kurangnya kepedulian sosial di sekitar lingkungan masyarakat. Sebagaimana Tabi'in menjelaskan bahwa zaman yang serba digital mendorong individu pada posisi individualistik, hal ini terlihat ketika terjadi sebuah kejadian ketika ada teman atau orang lain jatuh (tertimpa musibah), hal pertama yang dilakukan bukanlah menolongnya (Tabi'in, 2017). Namun justru sebaliknya beberapa individu lebih sibuk mengabadikan momen tersebut dengan memvidio, memotret, atau menyebarkan pada jejaring media sosial (Twenge, 2013).

Berdasarkan beberapa literature review di atas, maka dapat disimpulkan tentang seberapa penting menumbuhkan karakter peduli sosial, terutama dalam lembaga pendidikan yang di dalamnya 
terdapat interaksi antara pendidik dan peserta didik. Beerawal dari inilah masih terdapat satu ruang diskusi yang memerperlukan riset secara mendalam dan spesifik, yaitu tentang peran guru kelas (pendidik) di tingkat dasar (SD/MI) dalam proses menumbuhkan karakter sosial pada diri siswa. Penanaman karakter peduli sosial sedini mungkin pada siswa sangatlah tepat karena siswa sekolah dasar lebih banyak meniru dan melaksankan arahan yang diberikan pendidik kepadanya. Hal tersebut didukung dengan adanya sebuah lembaga tingkat sekolah dasar di Jawa Timur, tepatnya di Kota Gresik Kecamatan Menganti. Sekolah Dasar Muhammadiyah 1 Menganti Gresik menjadi salah satu sekolah dasar yang terbangun dengan mental peduli sosial pada diri siswa untuk peduli kepada masyarakat yang membutuhkan di lingkungan sekitar. Beberapa praktik yang dapat terlihat adalah pembagian daging hewan kurban oleh siswa kepada masyarakat, rutinitas infaq pada setiap kelas untuk di masukkan pada Lazizmu, selain itu pada momen bencana duka Sekolah Dasar Muhammadiyah 1 Menganti menjadi salah satu sekolah dasar yang tanggap dalam memberikan bantun kepada korban bencana baik secara langsung maupun tidak langsung (Jesica Dwi Rahmayanti \& Muhamad Arif, 2021). Berawal dari hal tersebut peneliti tertarik untuk mengetahui tentang bagaimana tahapan penanaman karakter peduli sosial pada peserta didik di Sekolah Dasar Muhammadiyah 1 Menganti Gresik?, dan apa saja kendala yang dihadapi dalam menanamkan karakter peduli sosial pada peserta didik Sekolah Dasar Muhammadiyah 1 Menganti Gresik?

\section{METODE}

Metode penelitian menggunakan metode kualitatif dengan pendekatan studi kasus (Yin, 2018). Sebagaimana latar empiris pada pendahuluan, Sekolah Dasar Muhammadiyah 1 Menganti Gresik menjadi salah satu sekolah dasar yang cukup tanggap dalam memberikan kepekaan sosial pada diri siswa. Hal tersebut terlihat pada beberapa dokumentasi sekolah yang masuk baik pada dunia digital (media sosial) maupun tertata secara offline. Sumber data primer pada penelitian ini yaitu guru kelas mulai dari kelas 1-6. Guru kelas mempunyai intensitas pertemuan yang cukup banyak dibandingkan guru mata pelajaran. Metode pengumpulan data menggunakan observasi partisipatif. Oleh karena posisi dari salah satu peneliti adalah guru kelas di Sekolah Dasar Muhammadiyah 1 Menganti Gresik, maka dilakukan wawancara semi terstruktur kepada seluruh guru kelas dan memaksimalkan dokumentasi yang terdapat pada Sekolah Dasar Muhammadiyah 1 Menganti Gresik. Dalam proses pengumpulan data peneliti menggunakan teknik analisis data dari Miles and Hubarman, kondensasi data, data display dan pencatatan kesimpulan (Miles et al., 2014). Untuk mengurangi pembiasan data, peneliti menggunakan uji keabsahan data dari Quin Patton yaitu triangulasi sumber. Secara aplikatif yaitu menggunakan sumber data dari guru kelas yang sama namun menggunakan metode yang 
berbeda. Sedangkan triangulasi metode, menggunakan metode yang sama seperti wawancara namun dilakukan kepada guru kelas (sumber) yang berbeda (Patton, 2015).

\section{HASIL PENELITIAN}

\section{Penanaman Karakter Peduli Sosial Pada Peserta Didik Di Sekolah Dasar Muhammadiyah 1 Menganti Gresik}

Guru kelas dalam proses penanaman karakter peduli sosial di SDI Muhammadiyah 1 Menganti melalui beberapa langkah. Sebagaimana yang disampaikan oleh SW 1-A bahwa dalam menanamkan karakter peduli sosial melalui pendampingan siswa untuk melakukan beberapa kegiatan secara rutin dan terjadwal, sehingga kegiatan itu sudah menjadi pembiasaan bagi peserta didik. Hal yang dilakukan seperti tolong menolong, menjenguk teman yang terkena musibah sakit atau dalam kondisi berduka. Ketika pembelajaran, guru kelas membiasakan peserta didik untuk menggunakan alat tulis seperti gunting, krayon, rautan secara berkelompok, dengan begitu peserta didik akan belajar melatih ego sehingga memunculkan sifat peduli dengan kebutuhan teman-teman di sekitarnya. Selain melakukan pembiasaan, beberapa program sekolah juga mendukung kepedulian lainnya seperti filantropis. Program tersebut di awali sejak tahun 2018 serta bekerja sama dengan LAZISMU Kabupaten Gresik. Program tersebut dibuat untuk menumbuhkan rasa gemar berinfaq pada siswa. Pada proses pelaksanaannya setiap peserta didik mendapatkan satu kaleng yang digunakan untuk berinfaq pribadi setiap hari sesuai kemampuannya. Setelah genap satu bulan, pihak sekolah sebagai pimpinan tertinggi menyalurkan kepada LAZISMU Kabupaten Gresik. Dengan demikian dapat diberikan kepada saudara yang membutuhkan.

Penanaman karakter peduli sosial menjadi salah satu program yang terus dilakukan, sebagaimana amanah kementrian pendidikan dan kebudayaan dalam penguatan pendidikan karakter. Proses penanaman yang dilakukan FS guru kelas II-A, bahwa selaku guru kelas mencoba semaksimal mungkin melakukan contoh berupa pembiasaan pada peserta didik seperti membantu teman yang sedang sakit atau yang sedang mengalami kesulitan, berbagi makanan dengan teman, menjenguk teman yang sakit, bertakziah ke rumah teman yang sedang berduka, berinfaq melalui program filantropis, dan donasi untuk korban bencana alam. Selain itu guru kelas menyelipkan penguatan ke dalam pembelajaran, seperti pembelajaran PPKn materi tentang tolong menolong, di sana guru kelas memberikan penguatan tentang bentuk dan pentingnya tolong menolong kepada sesama. Salah satu praktek yang dilakukan pada bulam ramadan yaitu adanya program takjil on the road, sebuah proses peserta didik berbagi kepada orang-orang yang melintas di depan sekolah sebelum waktu berbuka tanpa memilih. Tujuannya untuk melatih dan membiasakan peserta didik tentang indahnya berbagi 
dengan sesama. Saat pembelajaran peserta didik didorong untuk menggunakan alat tulis seperti krayon dan gunting dengan cara berkelompok.

Beberapa tahapan yang dilakukan untuk menanamkan karakter peduli sosial pada peserta didik juga dilakukan oleh AJS selaku guru kelas III-B yang menyampaikan bahwa karakter peduli sosial di Sekolah Dasar Muhammadiyah 1 Menganti Gresik dibiasakan melalui kegiatan yang dilakukan secara bertahap dan continue kepada peserta didik, seperti infaq melalui program filantropis, menjenguk dan membantu teman yang mendapatkan musibah, bertakziah ke keluarga teman yang berduka, kemudian mengumpulkan bantuan untuk korban bencana alam sebagai rasa duka kepada sesama. Seperti saat terjadi gempa dan tsunami di wilayah Sulawesi, Malang dan beberapa daerah lainnya. Donasi bencana alam yang terkumpul dari peserta didik diserahkan kepada LAZISMU Kabupaten Gresik, kemudian disalurkan kepada pihak yang terdampak bencana alam. Kegiatan ini rutin dilaksanakan baik sebelum dan saat terjadi pandemi.

Pada saat sebelum pandemi anak-anak langsung menyerahkan infaq kepada wali kelas, kemudian selama pandemi berlangsung anak-anak mengumpulkan infaqnya ketika pengambilan/pengumpulan tugas tergantung pada waktu tertentu. Adanya kegiatan tersebut diharapkan peserta didik mampu memahami betapa pentingnya berbagi. Selain itu guru kelas juga mengingatkan untuk saling tolong menolong kepada sesama, baik itu dengan teman ataupun guru. Selain mengingatkan dan mengarahkan peserta didik, guru kelas turut serta dalam kegiatan berinfaq maupun donasi kepada korban bencana alam sebagai bentuk pemberian contoh (telandan) kepada peserta didik.

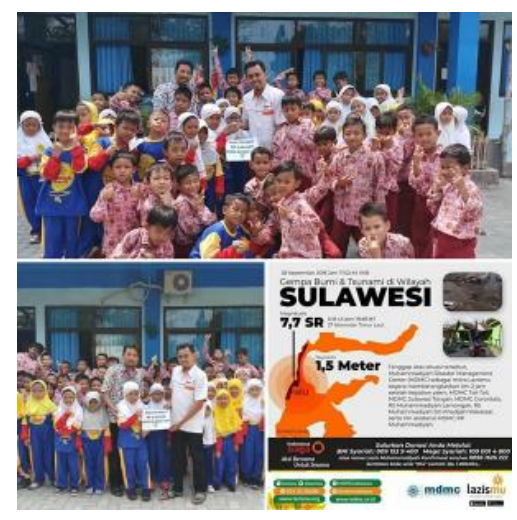

Gambar 1. Penyerahan Donasi Kepada LAZISMU Kabupaten Gresik

Hal senada, juga disampaikan oleh NAW selaku guru kelas IV-B, menjelaskan bahwa penanaman karakter peduli sosial dengan membiasakan peserta didik untuk membantu teman yang membutuhkan bantuan tidak hanya membiasakan, akan tetapi pendidik sebagai ustad-ustadzah juga ikut melakukannya agar dapat dijadikan teladan. Pendidik juga megarahkan kepada peserta didik untuk bersikap tolong menolong melalui penugasan piket kelas setiap hari. Melalui kegiatan tersebut 294 
siswa tidak hanya dilatih untuk peduli dengan sesama, akan tetapi juga menumbuhkan sikap tanggung jawab pada diri sendiri. Setiap harinya peserta didik diwajibkan untuk berinfaq melalui program sekolah yaitu filantropis. Salah satu tujuan program tersebut adalah mengajak peserta didik gemar berinfaq dan membiasakan siswa untuk berbagi dengan sesama. Sekolah Dasar Muhammadiyah 1 Menganti selalu menggalang donnasi pada saat terjadi bencana, seperti banjir di daerah Kecamatan Balongpanggang dan Benjeng Kabupaten Gresik yang setiap tahun terjadi. Kegiatan tahunan lainnya berupa penyembelihan hewan kurban, serta pembagian kepada masyarakat sekitar sekolah. Pada situasi pandemi pihak sekolah berkerja sama dengan LAZISMU Kabupaten Gresik mengadakan kurban untuk ketahanan pangan, yaitu daging hewan kurban sudah diolah berupa rendang kaleng. Hasil rendang kaleng didistribusikan ke negara-negara yang mengalami krisis kemanusiaan seperti Palestina dan Yaman.

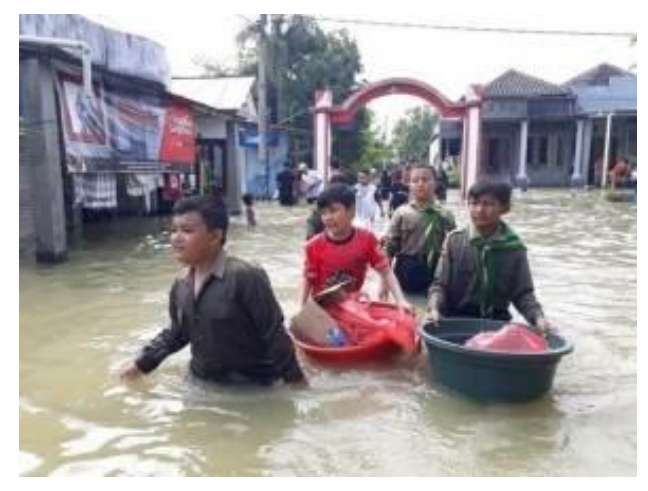

Gambar 2. Kegiatan Bakti Sosial Ke Korban Banjir di Kecamatan Benjeng dan Balongpanggang

Sejalan dengan yang disampaikan oleh IR selaku guru kelas V, menjelaskan bahwa dalam penanaman karakter peduli sosial, para guru menggunakan tahapan pembiasaan kepada peserta didik seperti membantu teman yang membutuhkan bantuan, bekerja sama saat melaksanakan tugas piket kelas, menginfaqkan sebagian uang sakunya untuk masyarakat yang kurang mampu melalui program filantropis, mengunjungi teman yang sedang sakit atau berduka, mengumpulkan bantuan berupa donasi untuk korban bencana alam berupa uang maupun benda seperti pakaian, buku, sembako, atau makanan ringan, dan ketika tempat dapat dijangkau peserta didik dan guru akan melaksanakan bakti sosial ke tempat-tempat yang terdampak bencana. Seperti beberapa bulan yang lalu, selaku guru mendampingi peserta didik untuk terjun bakti sosial kepada korban banjir di Desa Boboh, Kecamatan Menganti. Kegiatan tersebut diadakan untuk membiasakan peserta didik agar bersikap tolong menolong dan senantiasa bersyukur atas segala sesuatu yang sudah dimiliki. Sedangkan saat bulan ramadan mengadakan takjil on the road. Pada masa pandemi kegiatan digantikan dengan agenda berbagi sembako dan mengadakan kunjungan ke panti asuhan dan panti jompo di Kabupaten Gresik. Pentingnya penanaman peduli sosial diterapkan pada anak sejak sekolah dasar,juga di benarkan oleh DSW selaku guru kelas VI, yang menyatakan bahwa karakter harus dilakukan melalui pembiasaan 
sehingga muncul secara spontanitas. Begitu juga dalam karakter peduli sosial seperti pembiasaan melakukan donasi untuk masyarakat yang terkena musibah, menjenguk teman yang sakit, dan berinfaq yang nantinya diberikan kepada yang lebih membutuhkan. Selain itu para pendidik juga selalu mengingatkan kepada peserta didik untuk senantiasa membantu teman yang mengalami kesulitan. Melalui pembiasaan ini diharapkan peserta didik akan senang berbagi dengan masyarakat sekitar terutama yang membutuhkan bantuan tanpa adanya paksaan.

Berdasarkan dari beberapa hasil yang diperoleh dari wawancara, maka dapat disimpulkan bahwa penanaman karakter peduli sosial pada peserta didik di Sekolah Dasar Muhammadiyah 1 Menganti meliputi (1) Keteladanan, dalam hal ini guru tidak hanya mengarahkan dan mengingatkan siswa untuk bertindak tolong menolong, dan peduli terhadap sesama, akan tetapi guru juga melakukan hal yang sama sehingga dapat diambil sebagai teladan bagi peserta didik. (2) Pembiasaan, hal ini dilaksanakan melalui beberapa kegiatan secara rutin, sehingga kegiatan itu sudah menjadi kebiasaan bagi peserta didik. Kegiatan tersebut meliputi tolong menolong, menjenguk, mengunjungi teman yang sedang berduka, menggunakan alat tulis secara berkelompok, berinfaq, dan beberapa program kegiatan yang lainnya.

Sekolah Dasar Muhammadiyah 1 Menganti Gresik juga memberikan beberapa program kegiatan untuk mendukung penanaman karakter peduli sosial pada peserta didik. Pertama, filantropi. Program tersebut diawali pada tahun 2018 dan bekerja sama dengan LAZISMU Kabupaten Gresik. Program tersebut dibuat untuk menumbuhkan rasa gemar berinfaq pada peserta didik. Dalam pelaksanaannya setiap siswa mendapat 1 kaleng setiap peserta didik wajib mengisi kaleng tersebut setiap harinya dengan kemampuan masing-masing. Pada satu bulan sekali kaleng tersebut disetorkan kepada pihak sekolah, kemudian pihak sekolah menyetorkan kepada pihak LAZISMU Kabupaten Gresik untuk disalurkan kepada saudara yang kurang mampu. Kedua, takjil on the road, merupakan kegiatan rutin setiap bulan ramadan. Dalam kegiatan tersebut peserta didik diarahkan untuk membagikan makanan kecil kepada orang-orang yang melintas di depan SD Muhammadiyah 1 Menganti sebelum waktu berbuka. Tujuannya untuk melatih dan membiasakan peserta didikdalam memahami indahnya berbagi dengan sesama. Ketiga, donasi. Peserta didik diarahkan untuk memberikan infaq terbaiknya yang kemudian didonasikan kepada korban bencana alam, salah satunya gempa dan tsunami yang pernah terjadi di wilayah Sulawesi. Donasi yang diberikan tidak hanya berupa uang melainkan juga berupa pakaian, buku, sembako, atau makanan ringan. Dalam program ini, Sekolah Dasar Muhammadiyah 1 Menganti Gresik bekerjasama dengan LAZISMU Kabupaten Gresik dalam hal penyaluran donasi. 
Keempat, bakti sosial. Dalam program kegiatan bakti sosial guru mendampingi peserta didik untuk terjun ke tempat yang terdampak musibah. Melalui kegiatan tersebut diharapkan siswa terbiasa bersikap tolong menolong dan senantiasa bersyukur atas segala sesuatu yang sudah dimiliki. Kelima, pembagian daging qurban. Kegiatan tersebut dilaksanakan untuk merayakan hari raya idul adha dengan mengadakan penyembelihan hewan kurban di sekolah secara bersama, yang mana daging hasil penyembelihan dibagikan ke masyarakat sekitar sekolah. Melalui kegiatan tersebut diharapkan siswa terbiasa berbagi dengan masyarakat sekitar terutama yang membutuhkan bantuan. Serta adanya kurban ketahanan pangan, program ini dilaksanakan sebagai pengganti program penyembelihan hewan kurban yang telah dilaksanakan setiap tahun di sekolah. Sekolah Dasar Muhammadiyah 1 Menganti Gresik bekerjasama dengan LAZISMU Kabupaten Gresik, daging kurban diolah dan dikemas menjadi produk rendang kaleng. Produk tersebut didistribusikan ke negara-negara yang mengalami krisis kemanusiaan seperti Palestina dan Yaman.

\section{Kendala Penanaman Karakter Peduli Sosial Pada Peserta Didik Di Sekolah Dasar Muhammadiyah 1 Menganti Gresik}

Pada penanaman karakter peduli sosial peserta didik di Sekolah Dasar Muhammadiyah 1 Menganti memberikan dampak positif bagi perkembangan peserta didik serta kemajuan sekolah. Selain itu dapat menjalankan amanah negara untuk menguatkan pendidikan karakter pada peserta didik. Akan tetapi dalam pelaksanaannya ditemukan beberapa kendala. Hal tersebut disampaikan oleh SW selaku guru kelas I-A bahwa saat ini yang cukup perlu pemahaman adalah pada peserta didik kelas 1. Peserta didik di kelas bawah awal membutuhkan arahan terkait pembiasaan dan teladan secara inklusif. Namun, masih terdapat beberapa anak belum menyadari pentingnya bersikap peduli terhadap kondisi di sekitar (acuh tak acuh). Hal tersebut akan berpengaruh pada peserta didik lainnya. Untuk mengatasi hal tersebut, guru kelas selalu berusaha memberikan penguatan pada peserta didik tentang pentingnya peduli sekitar, sehingga peserta didik tidak hanya mampu melakukan tindakan, akan tetapi peserta didik mengetahui makna tentang mengapa harus melakukan tindakan tersebut.

Hal senada juga disampaikan oleh FS selaku guru kelas II-A, bahwa kendala masih ada pada beberapa peserta didik yang belum memahami tentang hasil dari peduli kepada sekitar. Kelas bawah menjadi catatan beberapa guru kelas agar dapat ekstra dalam memberikan tauladan, pemahaman, serta pendampingan dalam melakukan kegiatan. Untuk mengatasinya guru kelas melakukan pendekatakan pada peserta didik yang kurang aktif dalam beberapa pembiasaan peduli sosial melalui pemberian reward untuk memacu semangat peserta didik agar berlomba-lomba melakukan kebaikan. Sedangkan AJS selaku guru kelas III-B menyampaikan bahwa kendala yang ditemukan yaitu masih terdapat beberapa siswa yang kurang sadar untuk peduli dengan sekitarnya. Sikap seperti itulah yang akan 
mempengaruhi perkembangan sikap antara satu individu dengan individu lainnya. Dalam menanggulangi kendala tersebut, para guru melakukan pendekatan dan berkoordinasi dengan orang tua dengan mengadakan parenting setiap semester, sebagai khazanah ilmu tentang pendidikan anak kepada para wali murid.

Keadaan kendala dalam penanaman karakter peduli sosial juga di sampaikan NAW selaku guru kelas IV-B, tentang adanya peserta didik yang kurang mengikuti arahan guru. Hal ini disebabkan karena kurangnya kesadaran pada diri individu, serta tingginya ego pada masing-masing individu. Salah satu cara mengatasinya yaitu dengan memberikan reward agar peserta didik lebih semangat dalam mengikuti pembelajaran maupun pembiasaan pada arahan guru. Senada dengan yang disampaikan oleh IR selaku guru kelas V bahwa kendala sering dialami guru kelas yaitu ditemukannya beberapa peserta didik yang terkadang sulit untuk bersikap peduli dengan lingkungan sekitar, karena kurangnya kesadaran pada dirinya. Bahkan ditemukan beberapa peserta didik justru pilih-pilih teman jila akan membantu teman. Hal tersebut disebabkan karena pengaruh perkembangan teknologi salah satunya disebabkan oleh tayangan TV yang mempertontonkan adegan kurang mendidik. Untuk mengatasi hal tersebut, guru selalu mengingatkan peserta didik tentang pentingnya bersikap peduli dan tolong menolong, serta mengadakan program parenting setiap semester.

DSW guru kelas VI juga menyampaikan bahwa selama menanamkan karakter yang sering ditemui adalah kurangnya kesadaran pada diri anak tentang pentingnya peduli kepada sesama. Perkembangan sikap pada anak yang berbeda disebabkan pengaruh lingkungan luar sekolah, misalnya karena sarana hiburannya ketika di rumah dan candu dalam bermain game. Untuk mengatasinya, guru kelas memberikan penguatan kepada pesertya didik dengan memantau perkembangannya selama di rumah melalui buku penghubung dan berkoordinasi dengan orang tua untuk selalu memantau kegiatan selama di rumah melalui grup whatsapp kelas.

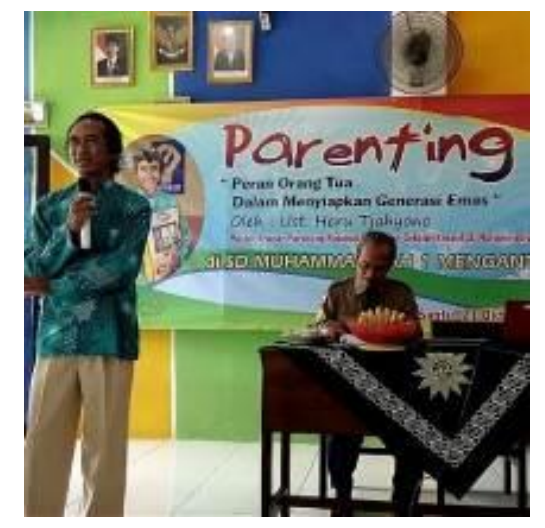

Gambar 3. Kegiatan Parenting yang Diadakan oleh Sekolah Dasar Muhammadiyah 1 Menganti Gresik

Berdasarkan hasil pengumpulan data di atas dapat diambil kesimpulan tentang fokus masalah beberapa kendala dalam menanamkan karakter peduli sosial pada peserta didik di Sekolah Dasar 298 
Muhammadiyah 1 Menganti Gresik meliputi, (1) Kurangnya kesadaran peserta didik tentang pentingnya tolong menolong serta peduli terhadap sesama. Untuk mengatasi masalah tersebut, guru kelas melakukan pendekatan dan penguatan tentang pentingnya bersikap tolong menolong serta peduli kepada sesama. Selain itu, guru kelas memberikan reward untuk memotivasi kepada peserta didik agar lebih semangat dalam mengikuti pembelajaran maupun pembiasaan dan arahan guru. (2) Perbedaan perkembangan sikap pada anak yang disebabkan karena pengaruh di lingkungan luar sekolah, seperti kecanduan dalam bermain game serta tayangan televisi yang kurang mendidik. Dalam mengatasi kendala ini guru Sekolah Dasar Muhammadiyah 1 Menganti Gresik melakukan koordinasi dengan orang tua agar senantiasa memantau kegiatan anak selama di rumah, menggunakan buku penghubung sebagai sarana dalam memantau kegiatan anak di rumah, dan mengadakan program parenting setiap semester untuk menambah wawasan kepada orang tua tentang pendidikan anak.

\section{PEMBAHASAN}

\section{Penanaman Karakter Peduli Sosial pada Peserta Didik di Sekolah Dasar Muhammadiyah 1 Menganti Gresik}

Penanaman pendidikan karakter menjadi tujuan dari pemerintah Indonesia, (Duryat \& Alphan, 2021) dalam menuju Indonesia emas di tahun 2045, hal tersebut diamantkan dalam permendikbud melalui 18 pendidikan karakter (Hartono, 2014). Sebagaimana negara Jepang memberikan kewajiban penanaman karakter pada diri peserta didik melalui apa tahapan, salah satunya yaitu memasukkan classtime pada kurikulum sekolah dasar (Bamkin, 2020). Tahapan demikian juga dilakukan Sekolah Dasar Muhammadiyah 1 Menganti Gresik kepada peserta didik dalam menanamkan karakter khususnya karakter peduli sosial (Muhaimin, 2017). Berikut beberapa hal dalam penanaman karakter peduli social.

a. Keteladanan

Pada posisi ini, guru tidak hanya mengarahkan dan mengingatkan siswa untuk bertindak dan peduli terhadap sesama (Prasetyo \& Marzuki, 2016), tetapi guru juga melakukan hal yang sama sehingga dapat diambil sebagai teladan bagi peserta didik (Hartono, 2014; Viningsih \& Listyaningsih, 2020). Posisi guru kelas sebagai teladan dalam penanaman karakter (Aini \& Syamwil, 2020; Sutisna et al., 2019) bagi peserta didik sangatlah diutamakan, terlebih peserta didik yang setiap hari bertatap muka dengan guru secara langsung (Busyaeri \& Muharom, 2016; Karso, 2019). Hal senada disampaikan Budiyanto dan Himmah dengan hasil risetnya mengatakan bahwa keteladanan menjadi salah satu kunci utama dalam mensukseskan penanaman karakter peduli sosial pada peserta didik (Budiyanto, 2016; Himmah \& 
Mulianingsih, 2019). Richardson mencatat tentang pentingnya guru dalam menanamkan pendidikan karakter melalui contoh yang dapat dilihat oleh peserta didik terutama karakter sosial. Karena karakter peduli sosial selain diperlukan pada sekolah, peduli sosial juga dibutuhkan di tengah masyarakat (Richardson et al., 2009). Dengan demikian pihak sekolah dan guru diharuskan dapat memberikan terobosan terbaiknya dalam menanamkan pendidikan karakter peduli sosial (Nguyen et al., 2021).

b. Pembiasaan

Penanaman pendidikan karakter tidak dapat dilakukan secara instan, maka sekolah dituntut untuk terus melakukan terobosan agar dapat sampai pada tujuannya (Murniyetti et al., 2016). Salah satu cara yang dilakukan guru kelas di Sekolah Dasar Muhammadiyah 1 Menganti yaitu dengan menerapkan pembiasaan dari beberapa kegiatan secara continue, sehingga penanaman karakter sosial dapat berjalan secara maksimal (Septyawan, 2018). Okeke and Drake dalam risetnya memberikan catatan bahwa posisi guru seharusnya tidak hanya menyelesaikan kewajiban yang bersifat akademik, namun guru harus bisa menjadikan peserta didik sebagai individu yang berprilaku baik serta memiliki karakter sosial yang dapat diterima dimasyarakat (Okeke \& Drake, 2014). Beberapa kegiatan seperti tolong menolong (Cahyo \& Djuwita, 2019; Okwita \& Aritra, 2019) menjadi kunci kesuksesan dalam menanamkan karakter peduli sosial pada peserta didik, karena didalamnya peserta didik mengalami secara langsung dari obyek yang membutuhkan tanpa adanya paksaan (Pertiwi, 2019), menjenguk, mengunjungi teman yang sedang berduka, (Sari, 2016) menggunakan alat tulis secara berkelompok, berinfaq, dan beberapa program kegiatan yang lainnya. Viningsih dan Listyaningsih dalam risetnya memberikan penguatan, bahwa salah satu cara dalam menanamkan karakter peduli sosial melalui kegiatan rutin (pembiasaan) (Viningsih \& Listyaningsih, 2020).

Selain kedua tahapan di atas, dalam melakukan proses penanaman karakter peduli sosial pada peserta didik Sekolah Dasar Muhammadiyah 1 Menganti Gresik memberikan beberapa program pendukung sebagai berikut.

a. Filantropi

Filantropis merupakan salah satu praktik kedermawanan individu sebagai salah satu sarana berbagi, seperti zakat, infaq, sedekah (Kasdi, 2016; Kholis et al., 2013; Ulza \& Kurniawan, 2018). Filantropis menjadi sebuah program Sekolah Dasar Muhammadiyah 1 Menganti di awal tahun 2018 bekerja sama dengan LAZISMU Kabupaten Gresik. Program ini dibuat untuk menumbuhkan rasa gemar berinfaq pada peserta didik (Ashari, 2016; Setiawatri \& Kosasih, 2019). Dalam pelaksanaannya setiap siswa mendapat satu kaleng dan wajib diisi setiap hari dengan kemampuan masing-masing. Setiap satu bulan sekali kaleng tersebut disetorkan kepada 
pihak sekolah kemudian pihak sekolah akan menyetorkan kepada pihak LAZISMU untuk disalurkan kepada saudara yang kurang mampu. Infaq menjadi program penanaman karakter sosial yang tepat, sebagaimana Irawan dalam risetnya, $4.72 \%$ responden (40 responden) menunjukkan bahwa berinfaq dapat menjadi alternatif dalam menumbuhkan sikap peduli sosial pada diri peserta didik (Irawan, 2019). Dikawati, juga menguatkan tentang pentingnya mempraktikkan berbagi melalui program infaq (Dikawati, 2019). Dengan berinfaq individu berlatih untuk menyisihkan sebagaian harta untuk membantu individu lain yang membutuhkan, disinilah esensi dari penanaman kepedulian sosial (Ulza \& Kurniawan, 2018).

b. Takjil On The Road

Salah satu kegiatan berbagi yang rutin dilaksanakan setiap bulan ramadan adalah berbagi takjil (Christian et al., 2020). Dalam kegiatan ini peserta didik diarahkan untuk membagikan makanan kecil kepada orang-orang yang melintas di depan SD Muhammadiyah 1 Menganti sebelum waktu berbuka, tujuannya untuk melatih dan membiasakan siswa tentang indahnya berbagi dengan sesama (Lestari \& Rohani, 2017; Wang et al., 2020). Hal senada juga disampaikan oleh Afrianty, Arif, dan Handayani bahwa kegiatan berbagi takjil di bulan ramadan menjadi salah satu program untuk menanamkan karakter puduli sosial pada peserta didik (Afrianty, 2018; Arif \& Handayani, 2020).

c. Donasi Korban Bencana Alam

Donasi kepada korban bencana alam merupakan sebuah gerakan sosial berupa tenaga, fikiran atau harta kepada sebagaian individu yang mengalami ujian berupa bencana alam.(Ningrum, 2020) Seperti contoh yang telah terjadi, yaitu korban bencana alam gempa bumi dan tsunami yang pernah terjadi di wilayah Sulawesi (Gempa Mamuju: Pengungsi Gempa Majene Mulai Kesulitan Makanan, Proses Evakuasi Korban Di Bawah Reruntuhan Masih Dilakukan - BBC News Indonesia, n.d.) Maka, guru kelas pada Sekolah Dasar Muhammadiyah 1 Menganti Gresik mempunyai kewajiban untuk mengajak peserta didik menyisihkan bantuan (donasi) berupa-rupa seperti uang pakaian, buku, sembako, atau makanan ringan (Astamal et al., 2021; Ruci et al., 2018). Dalam program ini, Sekolah Dasar Muhammadiyah 1 Menganti Gresik bekerja sama dengan LAZISMU Kabupaten Gresik dalam hal penyaluran donasi (Baidhawy, 2015). Dengan adanya penanaman karakter sosial melalui donasi kepada korban bencana alam, diharapkan peserta didik dapat lebih memahami pentingnya berbagi kepada sesama (Pertiwi, 2019).

\section{d. Bakti Sosial}

Program bakti sosial merupakan kegiatan membantu dengan turun ke lapangan secara langsung kepada individu, golongan, atau kelompok masyarakat yang terdampak musibah 
(Agustina et al., 2019). Guru kelas mendampingi peserta didik terjun ke lapangan untuk bakti sosial ke tempat musibah. Tambunan dan Fauzzia menjelaskan tentang pentingnya bakti sosial sebagai salah satu cara dalam menguatkan kepekaan sosial sesama manusia terlebih untuk peserta didik, karena dengan bakti sosial dapat meringankan beban musibah yang dihadapinya (Fauzzia et al., 2018; Tambunan et al., 2020). Melalui kegiatan tersebut diharapkan siswa terbiasa bersikap tolong menolong dan senantiasa bersyukur atas segala sesuatu yang sudah dimiliki.

e. Pembagian Daging Qurban dan Qurban Ketahanan Pangan

Pembagian daging kurban menjadi kegiatan rutinitas umat Islam di hari raya idul adha, di dalamnya terdapat agenda penyembelihan hewan kurban di masjid, musolla, dan sekolah (Sulaeman et al., 2019). Hal tersebut juga dilakukan oleh Sekolah Dasar Muhammadiyah 1 Menganti dalam menyembelih hewan kurban. Setelah melakukan penyembelihan hewan kurban, kemudian dibagikan kepada masyarakat sekitar sekolah. Amar menjelaskan tentang pentingnya penguatan kepekaan sosial pada diri peserta didik sedini mungkin melalui kegiatan sosial (Amar, 2017), seperti qurban yang diharapkan peserta didik dapat terbiasa berbagi dan tumbuhnya karakter peduli sosial dengan masyarakat sekitar terutama yang membutuhkan bantuan (Marlina et al., 2019).

Selain, program penyembelihan hewan kurban yang telah dilaksanakan setiap tahun, Sekolah Dasar Muhammadiyah 1 Menganti di masa pandemi Covid-19 juga bekerja sama dengan LAZISMU Kabupaten Gresik, menggadakan kurban ketahanan pangan yang berupa daging kurban diolah dan dikemas menjadi produk rendang kaleng. Produk tersebut didistribusikan ke negara-negara yang mengalami krisis kemanusiaan seperti Palestina dan Yaman (Wang et al., 2020).

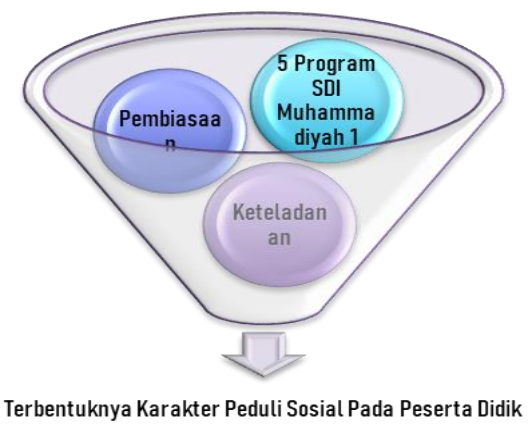

Gambar 4. Proses Penanaman Karakter Peduli Sosial

Pada Peserta Didik di Sekolah Dasar Muhammadiyah 1 Menganti Gresik 


\section{Kendala Penanaman Karakter Peduli Sosial Pada Peserta Didik Di Sekolah Dasar Muhammadiyah 1 Menganti Gresik}

Pada proses penanaman karakter peduli sosial di Sekolah Dasar Muhammadiyah 1 Menganti Gresik tidak selamanya berjalan tanpa kendala (Astamal et al., 2021). Hal senada disampaikan Masduqi tentang penumbuhan karakter peduli sosial melalui ekstrakurikuler (Masduqi, 2020). Sebagaimana hasil hasil wawancara, observasi, dan dokumentasi berdasarkan fokus masalah kendala dalam menanamkan karakter peduli sosial pada peserta didik di Sekolah Dasar Muhammadiyah 1 Menganti Gresik, (Busyaeri \& Muharom, 2016) yaitu sebagai berikut.

a. Kurangnya kesadaran peserta didik tentang pentingnya tolong menolong dan peduli terhadap sesama, terutama pada peserta didik tingkat bawah yang masih perlu pendampingan dalam proses penanaman karakter peduli sosial. Astamal dan Tabi'in juga memberikan catatan tentang pentingnya penguatan karakter peduli sosial, meskipun terkendala beberapa kendala. Karena karakter peduli sosial harus ditanamkan pada individu sedini mungkin (Astamal et al., 2021; Tabi'in, 2017). Untuk mengatasi masalah tersebut guru kelas melakukan pendekatan dan penguatan tentang pentingnya bersikap tolong menolong dan peduli kepada sesama (Viningsih \& Listyaningsih, 2020). Serta memberikan reward untuk memotivasi peserta didik agar lebih semangat dalam mengikuti pembelajaran dan arahan dari guru kelas (Arif \& Sulistianah, 2019).

b. Perbedaan perkembangan sikap pada peserta didik yang disebabkan karena pengaruh sarana hiburan, seperti game dan tayangan televisi. Untuk mengatasi hal tersebut guru Sekolah Dasar Muhammadiyah 1 Menganti Gresik melakukan koordinasi dengan orang tua agar senantiasa memantau kegiatan anak selama di rumah, menggunakan buku penghubung sebagai sarana dalam memantau kegiatan anak di rumah, dan mengadakan program parenting setiap semester untuk menambah wawasan kepada orang tua tentang pendidikan anak. Jesica dan Arif menyampaikan hal senada, bahwa program parenting menjadi sebuah solusi dari proses penguatan sinergisitas dan pemantauan antara guru, orang tua, dan peserta didik (Jesica Dwi Rahmayanti \& Muhamad Arif, 2021).

\section{KESIMPULAN}

Berdasarkan dari hasil dan pembahasan di atas riset ini dapat di ambil kesimpulan, bahwa dalam proses penanaman karakter peduli sosial pada peserta didik, terdapat dua tahapan yang dilakukan Sekolah Dasar Muhammadiyah 1 Menganti Gresik. Pertama, adalah keteladanan dari guru. Kedua, adalah pembiasaan yang harus dilakukan secara continue. Sedangkan dalam menguatkan kedua tahapan tersebut, Sekolah Dasar Muhammadiyah 1 Menganti Gresik, menggunakan beberapa 
program yaitu: Filantropi, Takjil on the road, Donasi korban bencana alam, Bakti sosial, pembagian daging qurban dan qurban ketahanan pangan. Dengan adanya program-program di atas, proses penanaman karakter peduli sosial pada peserta didik dapat berjalan secara maksimal. Namun, terlepas dari berbagai terobosan di atas, Sekolah Dasar Muhammadiyah 1 Menganti Gresik juga mengalami beberapa kendala, seperti: kurangnya kesadaran peserta didik tentang pentingnya tolong menolong dan peduli terhadap sesama, terutama pada peserta didik tingkat bawah yang masih perlu pendampingan dalam proses penanaman karakter peduli sosial. Dalam kendala ini guru mencoba memberikan reward sebagai salah satu motivasi pada peserta didik. Selain itu terdapatnya perbedaan perkembangan sikap pada peserta didik yang disebabkan karena pengaruh sarana hiburan, seperti game dan tayangan televisi, dalam menghadapi kendala ini, sekolah memberikan program parenting agar tercipta hubungan antara guru, orang tua dan peserta didik.

\section{DAFTAR PUSTAKA}

Abdusshomad, A. (2020). Pengaruh Covid-19 terhadap Penerapan Pendidikan Karakter dan Pendidikan Islam. QALAMUNA: Jurnal Pendidikan, Sosial, dan Agama, 12(2). https://doi.org/10.37680/qalamuna.v12i2.407

Afrianty, A. (2018). Peran Anggota Komunitas Berbagi Nasi (bernas) Dalam Membangun Sikap Peduli Sosial Masyarakat Di Kota Mojokerto. 6, 15.

Agustina, E., Rohmah, A., \& Kuspiyah, H. R. (2019). Pendampingan Bimbingan Belajar Bahasa Inggris dan Bakti Sosial di Yayasan Pendidikan dan Sosial Roudlotut Thullab. Jurnal Indonesia Mengabdi, 1(1), 15. https://doi.org/10.30599/jimi.v1i1.415

Aini, S. Q., \& Syamwil, F. (2020). Konstruksi Pendidikan Karakter Siswa Melalui Keteladanan Guru Di Sekolah. MANAGERE: Indonesian Journal of Educational Management, 2(2), 149-156. https://doi.org/10.52627/ijeam.v2i2.34

Amar, F. (2017). Implementasi Filantropi Islam di Indonesia. Al-Urban: Jurnal Ekonomi Syariah dan Filantropi Islam, 1(1), 1-14. https://doi.org/10.22236/alurban_vol1/is1pp1-14

Arif, M., \& Handayani, E. F. (2020). Budaya Literasi Madrasah Ibtidaiyah (Studi Kasus Madrasah Ibtidaiyah Miftahul Ulum Kesamben Wetan Driyorejo Gresik). MODELING: Jurnal Program Studi PGMI, 7(2), $198-220$.

Arif, M., \& Sulistianah, S. (2019). Problems in 2013 Curriculum Implementation for Classroom Teachers in Madrasah Ibtidaiyah. Al Ibtida: Jurnal Pendidikan Guru MI, 6(1), 110. https://doi.org/10.24235/al.ibtida.snj.v6i1.3916

Ashari, R. I. (2016). Implementasi Program Idb (infaq, Disiplin Dan Bersih) Dalam Meningkatkan Karakter Siswa Di Man Bondowoso Tahun Pelajaran 2016/2017. IAIN Jember. 
Astamal, A., Firman, F., \& Rusdinal, R. (2021). Pembentukan Karakter Peduli Sosial pada Siswa di SMAN 3 Payakumbuh. Jurnal Pendidikan Tambusai, 5(1), 79-84.

Baidhawy, Z. (2015). Lazismu and Remaking the Muhammadiyah's New Way of Philanthropy. Al-Jami'ah: Journal of Islamic Studies, 53(2), 387. https://doi.org/10.14421/ajis.2015.532.387-412

Bamkin, S. (2020). The taught curriculum of moral education at Japanese elementary school: The role of classtime in the broad curriculum. Contemporary Japan, 32(2), 218-239. https://doi.org/10.1080/18692729.2020.1747780

Budiyanto, A. (2016). Peran Guru Dalam Mengembangkan Kepedulian Sosial Siswa Dalam Kegiatan Pembelajaran Di Sekolah Dasar. Jurnal Pendidikan Dompet Dhuafa, 6(2), 5.

Busyaeri, A., \& Muharom, M. (2016). Pengaruh Sikap Guru Terhadap Pengembangan Karakter (peduli Sosial) Siswa Di Mi Madinatunnajah Kota Cirebon. Al Ibtida: Jurnal Pendidikan Guru MI, 2(1). https://doi.org/10.24235/al.ibtida.snj.v2i1.177

Cahyo, F. T., \& Djuwita, P. (2019). Studi Deskriptif Bentuk Permainan Kegiatan Kepramukaan Dalam Mengembangkan Sikap Tanggung Jawab Kerjasama Dan Tolong Menolong Pada Interaksi Sosial Siswa Sd Negeri 68 Kota Bengkulu. 11.

Christian, A., Rahmawati, E., Prihatin, T., Hazanah, E. K., Dwi, F., Lubis, I., \& Amri, N. O. (2020). Aksi Peduli Covid-19 Berupa Sosialisasi Hidup Sehat Dan Berbagi Sesama Insan. 2(1), 6.

Dikawati, A. A. (2019). Kegiatan Infaq Mingguan (jimpitan) Sebagai Implementasi Nilai-Nilai Kepedulian Sosial Di Desawatusomo Kecamatan Slogohimo Kabupaten Wonogiri [Skripsi]. IAIN Ponorogo.

Duryat, M., \& Alphan, A. (2021). Pendidikan Dan Perubahan Sosial: (Telaah Konseptual Pemikiran Pendidikan Mansour Fakih). K-Media.

Fauzzia, W., Sofiani, F., Shaleha, D. N., Malik, N. A., Delia, R., \& Rubianti, W. (2018). Pengabdian Kepada Masyarakat Bakti Sosial Bersama Jamaah Masjid Fatmah Hidayah. Jurnal Abdimas BSI: Jurnal Pengabdian Kepada Masyarakat, 1(1), 6.

Ganiem, L. M., \& dkk. (2015). PSR: Personal Social Responsibility: Aku, Kamu, Kita Bisa. Kencana.

Gempa Mamuju: Pengungsi gempa Majene mulai kesulitan makanan, proses evakuasi korban di bawah reruntuhan masih dilakukan-BBC News Indonesia. (n.d.). Retrieved 1 May 2021, from https://www.bbc.com/indonesia/indonesia-55671900

Hartono, H. (2014). Pendidikan Karakter Dalam Kurikulum 2013. Jurnal Budaya, 19(2), 259-268.

Himmah, F., \& Mulianingsih, F. (2019). Implementasi Pendidikan Karakter Peduli Sosial di SMP Negeri 1 Karangtengah Demak. 6.

Irawan, A. (2019). Sikap sosial siswa dalam kegiatan infaq. Atthulab: Islamic Religion Teaching and Learning Journal, 4(2), 225-235. https://doi.org/10.15575/ath.v4i2.4724 
Jesica Dwi Rahmayanti \& Muhamad Arif. (2021). Penerapan Full Day School Dalam Mengembangkan Budaya Religius di Sekolah Dasar Muhammadiyah 1 Menganti Gresik. eL Bidayah: Journal of Islamic Elementary Education, 3(1), 11-31. https://doi.org/10.33367/jiee.v3i1.1551

Karso, K. (2019). Keteladanan Guru dalam Proses Pendidikan di Sekolah. Prosiding Seminar Nasional Pendidikan Program Pascasarjana Universitas PGRI Palembang.

Kasdi, A. (2016). Filantropi Islam Untuk Pemberdayaan Ekonomi Umat (Model Pemberdayaan ZISWAF di BMT Se-Kabupaten Demak). IQTISHADIA Jurnal Kajian Ekonomi dan Bisnis Islam, 9(2), 227. https://doi.org/10.21043/iqtishadia.v9i2.1729

Kholis, N., Sobaya, S., Andriansyah, Y., \& Iqbal, M. (2013). Potret Filantropi Islam Di Propinsi Daerah Istimewa Yogyakarta. La_Riba, 7(1), 61-84. https://doi.org/10.20885/lariba.vol7.iss1.art5

Lestari, S., \& Rohani, R. (2017). Penanaman Karakter Peduli Sosial Di Sekolah Menengah Pertama Negeri 1 Tangaran Kabupaten Sambas. Jurnal Pendidikan Kewarganegaraan, 1(2).

Marlina, E., Isran Bidin, Zul Azmi, Adriyanti Agustina Putri, \& Rama Gita Suci. (2019). Tinjauan Sosial Ekonomi Dan Budaya Ibadah Qurban. Jurnal Pengabdian UntukMu NegeRI, 3(2), 243-247. https://doi.org/10.37859/jpumri.v3i2.1564

Masduqi, M. (2020). Menumbuhkan Karakter Peduli Sosial Melalui Kegiatan Ekstra-Kurikuler. Miyah, 16(1), 24.

Miles, Mattew. B., Hubarman, A. M., \& Saldana, J. (2014). Qualitative Data Analiysis A Metode Sourcebook Edition 3. Sage.

Muhaimin, A. (2017). Strategi Pendidikan Karakter Perspektif Kh. Hasyim Asy'ari. Nidhomul Haq, 2(1), 12. Murniyetti, M., Engkizar, E., \& Anwar, F. (2016). Pola Pelaksanaan Pendidikan Karakter Terhadap Siswa Sekolah Dasar. Jurnal Pendidikan Karakter, 6(2). https://doi.org/10.21831/jpk.v6i2.12045

Murray, B., Domina, T., Petts, A., Renzulli, L., \& Boylan, R. (2020). "We're in This Together": Bridging and Bonding Social Capital in Elementary School PTOs. American Educational Research Journal, 57(5), 2210-2244. https://doi.org/10.3102/0002831220908848

Nguyen, C. K., Tran, H. T., \& Nguyen, M. L. T. (2021). The Development of a Social Problem Solving Test for Elementary School Students. Journal of Rational-Emotive \& Cognitive-Behavior Therapy, 39(1), 35-57. https://doi.org/10.1007/s10942-020-00360-5

Ningrum, R. T. P. (2020). Potensi Modal Sosial Masyarakat Daerah Pasca Bencana Di Kabupaten Ponorogo. I-Economic: A Research Journal on Islamic Economics, 6(1), 24.

Nursalam, Nawir, M., Suardi, \& K, H. (2020). Model Pendidikan Karakter Pada Mata Pelajaran Ilmu Pengetahuan Sosial Di Sekolah Dasar. CV. AA RIZKY.

Nuryanto, M. A. (2008). Mazhab Pendidikan Kritis. Resist Book. 
Okeke, C., \& Drake, M. (2014). Teacher as Role Model: The South African Position on the Character of the Teacher. Mediterranean Journal of Social Sciences. https://doi.org/10.5901/mjss.2014.v5n20p1728

Okwita, A., \& Aritra, E. S. A. S. (2019). Perubahan Kehidupan Sosial Budaya Masyarakat Melayu Kampung Tua Tanjung Buntung Pasca Pembangunan. HISTORIA: Jurnal Program Studi Pendidikan Sejarah, 2(1). https://doi.org/10.33373/his.v2i1.1568

Patton, M. Q. (2015). Qualitative research \& evaluation methods: Integrating theory and practice (Fourth edition). SAGE Publications, Inc.

Pertiwi, M. E. (2019). Upaya guru IPS dalam meningkatkan pendidikan karakter peduli sosial melalui pembiasaan tolong menolong di kelas VII idaman SMP An-Nur Bululawang [Doctoral disertation]. Universitas Islam Negeri Maulana Malik Ibrahim Malang.

Prasetyo, D., \& Marzuki, M. (2016). Pembinaan Karakter Melalui Keteladanan Guru Pendidikan Kewarganegaraan Di Sekolah Islam Al Azhar Yogyakarta. Jurnal Pendidikan Karakter, 6(2). https://doi.org/10.21831/jpk.v6i2.12052

Richardson, R. C., Tolson, H., Huang, T.-Y., \& Lee, Y.-H. (2009). Character Education: Lessons for Teaching Social and Emotional Competence. Children \& Schools, 31(2), 71-78. https://doi.org/10.1093/cs/31.2.71

Rokhman, F., Hum, M., Syaifudin, A., \& Yuliati. (2014). Character Education for Golden Generation 2045 (National Character Building for Indonesian Golden Years). Procedia - Social and Behavioral Sciences, 141, 1161-1165. https://doi.org/10.1016/j.sbspro.2014.05.197

Ruci, L., van Allen, Z. M., \& Zelenski, J. M. (2018). Pro-social personality traits, helping behavior, and egodepletion: Is helping really easier for the dispositionally pro-social? Personality and Individual Differences, 120, 32-39. https://doi.org/10.1016/j.paid.2017.08.013

Sari, Y. M. (2016). Pembinaan Toleransi Dan Peduli Sosial Dalam Upaya Memantapkan Watak Kewarganegaraan (civic Disposition) Siswa. JURNAL PENDIDIKAN ILMU SOSIAL, 23(1). https://doi.org/10.17509/jpis.v23i1.2059

Septyawan, D. (2018). Analisis Film Upin \& Ipin Dalam Penanaman Karakter Peduli Sosial. Jurnal Sinektik, $1(1), 53-65$.

Setiawatri, N., \& Kosasih, A. (2019). Implementation of Social Care Character Education in the Pluralist Community of Pluralism in Cigugur Kuningan. Jurnal Pendidikan Karakter, 9(2), 14.

Sulaeman, S., Mahriani, R., \& Nurdin, A. (2019). Komunikasi Tradisi Abda'u pada Prosesi HewanQurban Adat Tulehu Maluku. KOMUNIKA: Jurnal Dakwah dan Komunikasi, 13(2). https://doi.org/10.24090/komunika.v13i2.2067 
Sutisna, D., Indraswati, D., \& Sobri, M. (2019). Keteladanan Guru sebagai Sarana Penerapan Pendidikan Karakter Siswa. JPDI (Jurnal Pendidikan Dasar Indonesia), 4(2), 29. https://doi.org/10.26737/jpdi.v4i2.1236

Tabi'in, A. (2017). Menumbuhkan Sikap Peduli Pada Anak Melalui Interaksi Kegiatan Sosial. IJTIMAIYA: Journal of Social Science Teaching, 1(1). https://doi.org/10.21043/ji.v1i1.3100

Tambunan, E., Purba, M. L., \& Haloho, E. (2020). Pendampingan Gerakan Bakti Sosial Berbagi Paket Sembako Peduli Covid-19 Hima Manajemen Universitas Sari Mutiara Indonesia. Jurnal Abdimas Mutiara, 1(2), 6 .

Twenge, J. M. (2013). Does Online Social Media Lead to Social Connection or Social Disconnection? Journal of College and Character, 14(1), 11-20. https://doi.org/10.1515/jcc-2013-0003

Ulza, E., \& Kurniawan, H. (2018). Strategi Pemberdayaan Pembangunan Sosial Melalui Gerakan Filantropi Islam. 2(1), 11.

Viningsih, T. V., \& Listyaningsih, L. (2020). Peran Guru PPKN Dalam Pembinaan Karakter Peduli Sosial Peserta Didik Di Sman 1 Gedangan Sidoarjo. Kajian Moral dan Kewarganegaraan, 08(02), 826-840.

Wang, C., Huang, J., Liao, J., \& Wan, X. (2020). Food Sharing With Choice: Influence on Social Evaluation. Frontiers in Psychology, 11, 2070. https://doi.org/10.3389/fpsyg.2020.02070

Wirawan, I. B. (2012). Teori-teori Sosial dalam Tiga Paradigma: Fakta sosial, definisi sosial, dan perilaku sosial. Kencana.

Yin, R. K. (2018). Case study research and applications: Design and methods (Sixth edition). SAGE. 